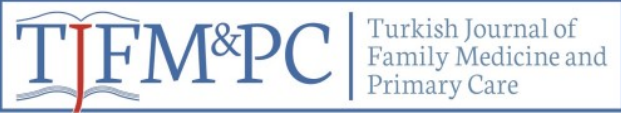

Original Research / Özgün Araştırma

\title{
The Effect of Care Needs on Quality of Life and Chronic Disease Care in Patients with Diabetes
}

\author{
Diyabetik Bireylerde Bakım Gereksinimlerinin Yaşam Kalitesi ve Kronik Hastalık \\ Bakımına Etkisi
}

Şenay Zuhur ${ }^{1}$, Nurhan Özpancar ${ }^{* 2}$

\begin{abstract}
Aim: The aim of this study was to investigate the effect of care needs on quality of life and chronic disease care in patients with type-2 diabetes. Methods: A cross-sectional and descriptive study. One hundred forty-five patients with type-2 diabetes who were followed-up between January 2016 and January 2017 in the university hospital were included in the study. The "Patient Presentation and Care Management Evaluation Form", "Quality of Life Assessment Scale (EQ-5D-5L)" and "Chronic Illness Care Assessment Scale-Patient Form (PACIC)" were used for the collection of data. One-way ANOVA test, Tukey HDS test, independent two-sample t-test, Kruskal Wallis test, Mann Whitney U test and Pearson correlation analysis were used for the evaluation of data.

Results: In this study, the average total PACIC score of patients with type-2 diabetes was found to be satisfactory (3.78 \pm 0.79 ). However, the EQ-5D-5L average score was found to be close to perfect $(0.84 \pm 0.17)$. A positive correlation was found between EQ-5D-5L scores and PACIC decision support and goal setting/guidance sub-scale scores, and a negative correlation was found between positive EQ-5D-5L score and body mass index and HbA1c values. A significant correlation was also found between current diabetes treatment compliance and the EQ-5D-5L general health score and PACIC total score. The PACIC decision support and goal setting/guidance sub-scales were found to be significantly different based on the diabetes education status of patients with type-2 diabetes. Conclusions: Planning health education and counseling programs for general care adjustment are recommended for chronic disease management of diabetes.
\end{abstract}

Keywords: Type 2 diabetes, care, chronic disease, quality of life

\section{ÖZET}

Amaç: Bu çalışmayla; tip 2 diyabetik bireylerde bakım gereksinimlerinin yaşam kalitesi ve kronik hastalık bakımına etkisinin incelenmesi amaçlandı. Yöntem: Kesitsel ve tanımlayıcı bir çalıșma. Üniversite hastanesinde Ocak 2016 - Ocak 2017 tarihleri arasında takip edilen tip 2 diyabetli 145 hasta çalışmaya dahil edildi. Verilerin toplanmasında "Hasta Tanıtım ve Bakım Yönetimi Değerlendirme Formu", "Yaşam Kalitesi Değerlendirme Ölçeği (EQ5D-5L)" ve "Kronik Hastalık Bakımını Değerlendirme Ölçeği-Hasta Formu (PACIC)" kullanıldı. Verilerin değerlendirilmesinde tek yönlü ANOVA testi, Tukey HDS testi, bağımsız iki örneklem t testi, Kruskal Wallis testi, Mann Whitney U testi ve Pearson korelasyon analizi kullanıldı. Bulgular: Bu çalışmada, tip 2 diyabetli hastaların ortalama toplam PACIC skorları tatmin edici bulundu (3.78 \pm 0.79$)$. Ancak, EQ-5D-5L ortalama skorunun mükemmele yakın olduğu bulundu $(0,84 \pm 0,17)$. EQ-5D-5L puanları ile PACIC karar desteği ve hedef belirleme / rehberlik alt ölçek puanları arasında pozitif, EQ-5D-5L skoru ve beden kitle indeksi ile HbA1c değerleri arasında negatif bir korelasyon bulundu. Mevcut diyabet tedavisine uyum ile EQ-5D-5L genel sağlık skoru ve PACIC toplam skoru arasında da anlamlı bir ilişki bulundu. PACIC karar desteği ve hedef belirleme / rehberlik alt ölçeklerinin tip 2 diyabetli hastaların diyabet eğitimi durumuna göre anlamlı derecede farklı olduğu bulundu. Sonuçlar: Araştırma sonucunda, tip 2 diyabetlilerin kronik hastalık bakım yönetiminde; genel tedaviye uyumu için sağlık eğitimi ve danışmanlık programları planlanması önerilebilir.

Anahtar Sözcükler: Tip 2 diyabet, bakım, kronik hastalık, yaşam kalitesi

Received date / Geliş tarihi: 21.08.2019, Accepted date / Kabul tarihi: 10.11 .2019

${ }^{1}$ Endocrinology and Metabolism Diseases Clinic, Health Practice and Research Center, Tekirdag Namık Kemal University, Tekirdağ, TURKEY.

${ }^{2}$ Tekirdag Namık Kemal University School of Health, Nursing Department Tekirdag, TURKEY.

*Address for Correspondence / Yazışma Adresi: Nurhan Ö̉zpancar, Tekirdag Namık Kemal University School of Health, Nursing Department Tekirdag, TURKEY.

E-mail: nurhan25@hotmail.com

Zuhur S, Ozpancar N. The Effect of Care Needs on Quality of Life and Chronic Disease Care in Patients with Diabetes. TJFMPC, 2020;14(1): 56-65.

DOI: $10.21763 /$ tjfmpc.693078 


\section{INTRODUCTION}

Chronic diseases constitute an important portion of deaths in adulthood and their importance is increasing worldwide. ${ }^{1}$ Type 2 diabetes, which is a chronic disease, is a global health problem that is increasing in importance globally due to its prevalence and the problems it creates, causing workload loss, financial burden, chronically and adversely affecting the quality of life. It is estimated that 425 million people worldwide have Type 2 diabetes and this figure is expected to reach 629 million people by 2045 . It was reported that 5 million people aged between 20-79 years have lost their lives due to Type 2 diabetes and complications and this ratio constitutes $14.5 \%$ of all causes of death worldwide. ${ }^{2}$ In Turkey; the prevalence of diabetes in adults over 20 years of age has increased from $7.2 \%$ to $16.5 \%$ in 12 years, and this figure is $13.7 \%$ in the standardization of 2009 official Turkish population according to age distribution. The incidence of Type 2 diabetes in children and adolescents is increasing rapidly in recent years due to nutrition, inactivity and inadequate lifestyle. ${ }^{3}$ When we examine the 2015 report of the International Diabetes Federation (IDF), the cost of prevention and treatment of Type 2 diabetes and Type 2 diabetes globally exceeds US \$ 802 billion. ${ }^{4}$ Early diagnosis, appropriate treatment, and effective management of Type 2 diabetes are important to reduce the burden of Type 2 diabetes on the individual and the community. The presence of Type 2 diabetes may also cause macrovascular problems such as coronary heart disease, cerebrovascular diseases and peripheral vascular diseases at an early age and may lead to a more aggressive progression, which may adversely affect the quality of life of patients. ${ }^{5}$ Nowadays, the spread of chronic diseases reveals the importance of chronic disease management programs. Effective chronic disease management may allow the patient to gain self-management skills. ${ }^{1}$ A significant portion of care is done by Type 2 diabetes patients, themselves. Increasing the awareness and selfmanagement skills of Type 2 diabetes patients are possible with sustainable education programs. The health outcomes are affected positively among individuals who have learned disease management, their quality of life increases and the cost associated with their disease decreases significantly.

In addition, one-to-one patient follow-up, regular glucose level monitoring, insulin therapy support, regulation of individual nutrition programs, screening, and controls for complications, emotional support for patients such as emotional support are not met sufficiently during the care and follow-up of Type 2 diabetes. In this case, it is predicted that there is a negative impact on the quality of life patients with Type 2 diabetes. ${ }^{6}$ In the literature, studies to determine the care needs, to improve the management of care, quality of life, and chronic disease care of individuals with Type 2 diabetes is limited. The aim of this study was to investigate the effect of care needs on quality of life and chronic disease care in patients with Type 2 diabetes.

\section{METHODS}

\section{Research questions}

- What are the descriptive features and care needs of patients?

- Is there a difference between the care needs of patients and their quality of life and chronic disease-care?

- Is there a relationship between the quality of life of patients with Type 2 diabetes and the outcome of the assessment of chronic disease care?

\section{Study design and sample size}

The study was conducted as a crosssectional and descriptive study. The study population consisted of 723 registered patients aged 18 years and older who applied for follow-up and treatment of Type 2 diabetes between January 2016 and January 2017 in the Internal Medicine Department Endocrinology and Metabolism Diseases Clinic of a university hospital. The sample for the research was calculated as 145 for the study population according to the known sample calculation with $13.7 \%$ prevalence, $95 \%$ confidence interval and 5\% error margin. One hundred and fifty patients who accepted participation in the study voluntarily and who did not have communication disabilities formed the sample of the study. Patients with chronic disease (hypertension, liver failure, chronic renal failure, chronic heart failure, chronic obstructive lung disease, chronic arterial disease, cerebrovascular disease) other than Type 2 diabetes were excluded from the study.

\section{Data collection}

For the collection of data, the Patient Information and Care Management Evaluation Form, Quality of Life Assessment Scale (EQ-5D5L) and the Patient Assessment of Chronic Illness Care - Patient Form (PACIC) were used.

Patient Information and Care Management Evaluation Form: This form consists of a total of 32 questions describing the socio-demographic characteristics, diabetes treatment and 
characteristics of diabetes management in light of the literature. ${ }^{1,2,5}$

Quality of Life Assessment Scale (EQ-5D-5L): This is a self-report scale developed in 2009 by the EuroQoL group, which is used to measure the quality of life. EuroQoL is a research community in Western European performing quality of life research. The EQ-5D identifier system and the EQ visual analog scale (EQ-VAS) are two separate sections. The index scores are 0 value death and 1 value perfect health. The Visual Analog Scale (EQVAS) has a vertical line with numbers from 0-100. The individual's health status is marked best as "100 points" and worst is " 0 points". Quality of life increases as score increases. ${ }^{7}$

Patient Assessment of Chronic Illness Care Patient Form (PACIC): The Patient Assessment of Chronic Illness Care - Patient Form (PACIC) was developed by Glasgow et al. in $2005,{ }^{8}$ in a study about chronic diseases, such as hypertension, arthritis, depression, diabetes, and asthma. The total score of the scale is the average of all 20 items. The lowest total score is 1 , while the highest total score is 5. The Cronbach alpha coefficient of the scale was 0.93 according to the validity and reliability studies for the scale. ${ }^{9}$

\section{Ethical Considerations}

Ethical approval was obtained from the non-interventional research ethical committee of the Faculty of Medicine (Approval number: 2016/106/09/04 Date: 27/10/2016). All of the participants signed informed consent before participating.

\section{Statistical analysis}

The NCSS (Number Cruncher Statistical System) 2007 Statistical Software (NCSS LLC, Kaysville, Utah, USA) program was used. The evaluation of data used mean, standard deviation, median, frequency, and ratio. The one-way analysis of variance (ANOVA) test and the post hoc (Tukey) test were used to determine the difference between groups. The Kruskal-Wallis test and Mann-Whitney $U$ test was used for the determination of the group that caused the difference between the two groups. Pearson correlation analysis was used to evaluate the relationships between variables. $\mathrm{P}<0.05$ and $\mathrm{P}<0.01$ were considered significant.

\section{RESULTS}

The mean age of the patients was $52.75 \pm 8.70$ years (minimum: 31-maximum: 82 ); 58.7\% female,
$38.7 \%$ overweight and body mass index (BMI) average $30.60 \pm 5.95 \mathrm{~kg} / \mathrm{m}^{2}$. Of patients, $58 \%$ were primary school graduates, $97.3 \%$ were married, $36.7 \%$ were employed, $23.3 \%$ were smokers and $14.7 \%$ alcohol. In terms of diabetes, $32.7 \%$ of the patients had Type 2 diabetes for 4-6 years, 57.3\% of patients use oral antidiabetics and $95.3 \%$ of them receive insulin treatment. Type 2 diabetes education had been given to $54 \%$ of the patients and most thought that education was not sufficient. Blood glucose levels were monitored at home by $84 \%$ of the patients and $41.3 \%$ of the patients regularly record their results. Of patients, $45.3 \%$ stated that they exercised, $65.3 \%$ followed a diet and $45.3 \%$ had good compliance with treatment (Table 1). 
Table 1. Descriptive and care management characteristics of patients $(n=150)$

\begin{tabular}{|c|c|c|c|}
\hline & & $\begin{array}{l}\text { Minimum- } \\
\text { Maximum }\end{array}$ & $\begin{array}{l}\text { Mean } \pm \text { standard } \\
\text { deviation }\end{array}$ \\
\hline Age (year) & & $31-82$ & $52.75 \pm 8.70$ \\
\hline \multirow[t]{2}{*}{ Body mass index } & & $17.54-58.72$ & $30.60 \pm 5.95$ \\
\hline & & $\mathbf{n}$ & $\%$ \\
\hline \multirow[t]{2}{*}{ Gender } & Male & 62 & 41.3 \\
\hline & Female & 88 & 58.7 \\
\hline \multirow[t]{6}{*}{ Body mass index classification } & Low weight & 1 & 0.7 \\
\hline & Normal weight & 16 & 10.7 \\
\hline & Overweight & 58 & 38.7 \\
\hline & High obesity & 46 & 30.7 \\
\hline & Very high obesity & 20 & 13.3 \\
\hline & Morbid obesity & 9 & 6.0 \\
\hline \multirow[t]{3}{*}{ Education } & Primary education & 87 & 58.0 \\
\hline & High school & 30 & 20.0 \\
\hline & University & 33 & 22.0 \\
\hline \multirow[t]{2}{*}{ Marital status } & Single & 4 & 2.7 \\
\hline & Married & 146 & 97.3 \\
\hline \multirow[t]{2}{*}{ Employment status } & Yes & 55 & 36.7 \\
\hline & No & 95 & 63.3 \\
\hline \multirow[t]{3}{*}{ Smoking } & Current smoking & 35 & 23.3 \\
\hline & Non-smoker & 61 & 40.7 \\
\hline & Ex-smoking & 54 & 36.0 \\
\hline \multirow[t]{3}{*}{ Alcohol } & Alcohol & 22 & 14.7 \\
\hline & Alcohol-free & 101 & 67.3 \\
\hline & Ex-alcohol & 27 & 18.0 \\
\hline \multirow[t]{4}{*}{ Duration of diabetes (years) } & 1-3 year & 40 & 26.7 \\
\hline & 4-6 year & 49 & 32.7 \\
\hline & 7-9 year & 22 & 14.7 \\
\hline & $\geq 10$ year & 39 & 26.0 \\
\hline \multirow[t]{3}{*}{ Treatment } & Insulin & 2 & 1.3 \\
\hline & Oral antidiabetic & 86 & 57.3 \\
\hline & Insulin+oral antidiabetic & 62 & 41.3 \\
\hline \multirow[t]{2}{*}{ Self-application of insulin (n:64) } & Yes & 61 & 95.3 \\
\hline & No & 3 & 4.7 \\
\hline \multirow[t]{2}{*}{ Diabetes education } & Yes & 81 & 54.0 \\
\hline & No & 69 & 46.0 \\
\hline \multirow[t]{3}{*}{ Quality of education } & Yes & 31 & 20.7 \\
\hline & No & 81 & 54.0 \\
\hline & Partially & 38 & 25.3 \\
\hline \multirow[t]{2}{*}{ Self-applied blood glucose measurement } & Yes & 126 & 84.0 \\
\hline & No & 24 & 16.0 \\
\hline \multirow{3}{*}{$\begin{array}{l}\text { Regular recording of blood glucose results } \\
\text { (n: 126) }\end{array}$} & Yes & 52 & 1.3 \\
\hline & No & 48 & 38.1 \\
\hline & Sometimes & 26 & 20.6 \\
\hline \multirow{3}{*}{ Exercise } & Yes & 68 & 45.3 \\
\hline & No & 48 & 32.0 \\
\hline & Sometimes & 34 & 22.7 \\
\hline \multirow[t]{2}{*}{ Diet } & Yes & 98 & 65.3 \\
\hline & No & 52 & 34.7 \\
\hline \multirow{5}{*}{ Treatment adherence } & Very bad & 8 & 5.3 \\
\hline & $\mathrm{Bad}$ & 36 & 24.0 \\
\hline & Good & 68 & 45.3 \\
\hline & Very good & 32 & 21.4 \\
\hline & Excellent & 6 & 4.0 \\
\hline
\end{tabular}

There was a statistically significant correlation between treatment compliance level and EQ-5D-5L overall health score index value ( $\mathrm{r}: 0.166 ; \mathrm{P}<0.05)$ and VAS score (r: 0.165; $\mathrm{P}<0.05$ ). There was 
a statistically significant correlation between BMI values of patients and EQ-5D-5L overall health score index (r: -0.224; $\mathrm{P}<0.01$ ) and VAS score (r: -0.186; $\mathrm{P}<0.05)$. A statistically significant correlation was found between hemoglobin A1c (HbA1c) values and EQ-5D-5L overall health score index value $(\mathrm{r}:-0.188 ; \mathrm{P}<0.05)$ and VAS score (r: $-0.225 ; \mathrm{P}<0.01)$. A statistically significant difference was found in terms of the overall health score of the patients according to the diet status of the patients $(\mathrm{P}<0.01)$, and the scores of those who were on a regular diet were higher than those who did not follow a regular diet (Table 2).

Table 2. The relationship between patients' disease, care management, some metabolic variables and quality of life (EQ-5D-5L Overall Health Score) $(n=150)$

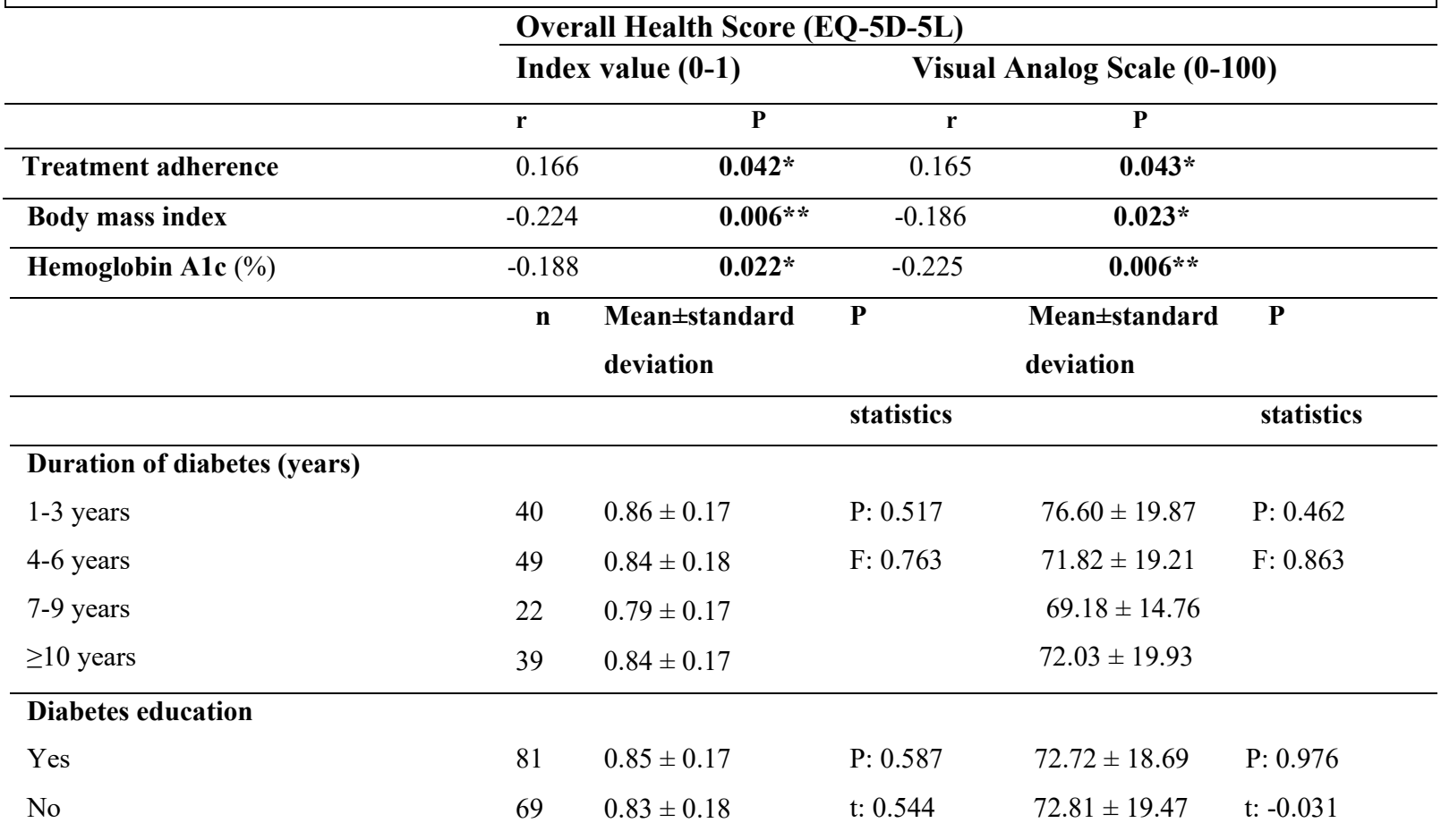

\section{Self-applied blood glucose}

measurement

\begin{tabular}{llllll} 
Yes & 126 & $0.83 \pm 0.17$ & P: 0.354 & $72.91 \pm 19.26$ & P: 0.822 \\
No & 24 & $0.87 \pm 0.16$ & t: -0.929 & $71.96 \pm 17.87$ & t: 0.225 \\
\hline Exercise & & & & & \\
Yes & 68 & $0.87 \pm 0.17$ & P: 0.111 & $74.46 \pm 19.40$ & P: 0.606 \\
No & 48 & $0.80 \pm 0.19$ & F: 2.228 & $71.60 \pm 18.76$ & F: 0.503 \\
Sometimes & 34 & $0.85 \pm 0.15$ & & $71.00 \pm 18.75$ & \\
\hline Diet & & & & & \\
Yes & 98 & $0.87 \pm 0.16$ & P: $\mathbf{0 . 0 0 3 * *}$ & $75.04 \pm 17.39$ & P: $\mathbf{0 . 0 4 3 * *}$ \\
No & 52 & $0.78 \pm 0.18$ & t: 3.059 & $68.46 \pm 21.20$ & t: 2.041
\end{tabular}

$\mathrm{r}$ : Pearson correlation coefficient, t: Independent groups t test, $\mathrm{F}$ : One-way analysis of variance, ${ }^{*} \mathrm{P}<0.05, \quad{ }^{* *} \mathrm{P}<0.01$

PACIC total score ( $\mathrm{r}: 0.178 ; \mathrm{P}<0.05$ ) was found to be positively correlated with treatment compliance level. There was a statistically significant correlation between treatment compliance level and decision-making support (r: 0.215; $\mathrm{P}<0.01)$ and goal determination/guidance (r: 0.185; $\mathrm{P}<0.05$ ) subscale scores. A statistically significant difference was found in PACIC decision-making support $(\mathrm{P}<0.05)$ and goal identification/guidance $(\mathrm{P}<0.05)$ sub-dimension scores according to patients receiving Type 2 diabetes education. It was determined that the scores for those with education were higher than the scores of those who did not receive education (Table 3 ). 


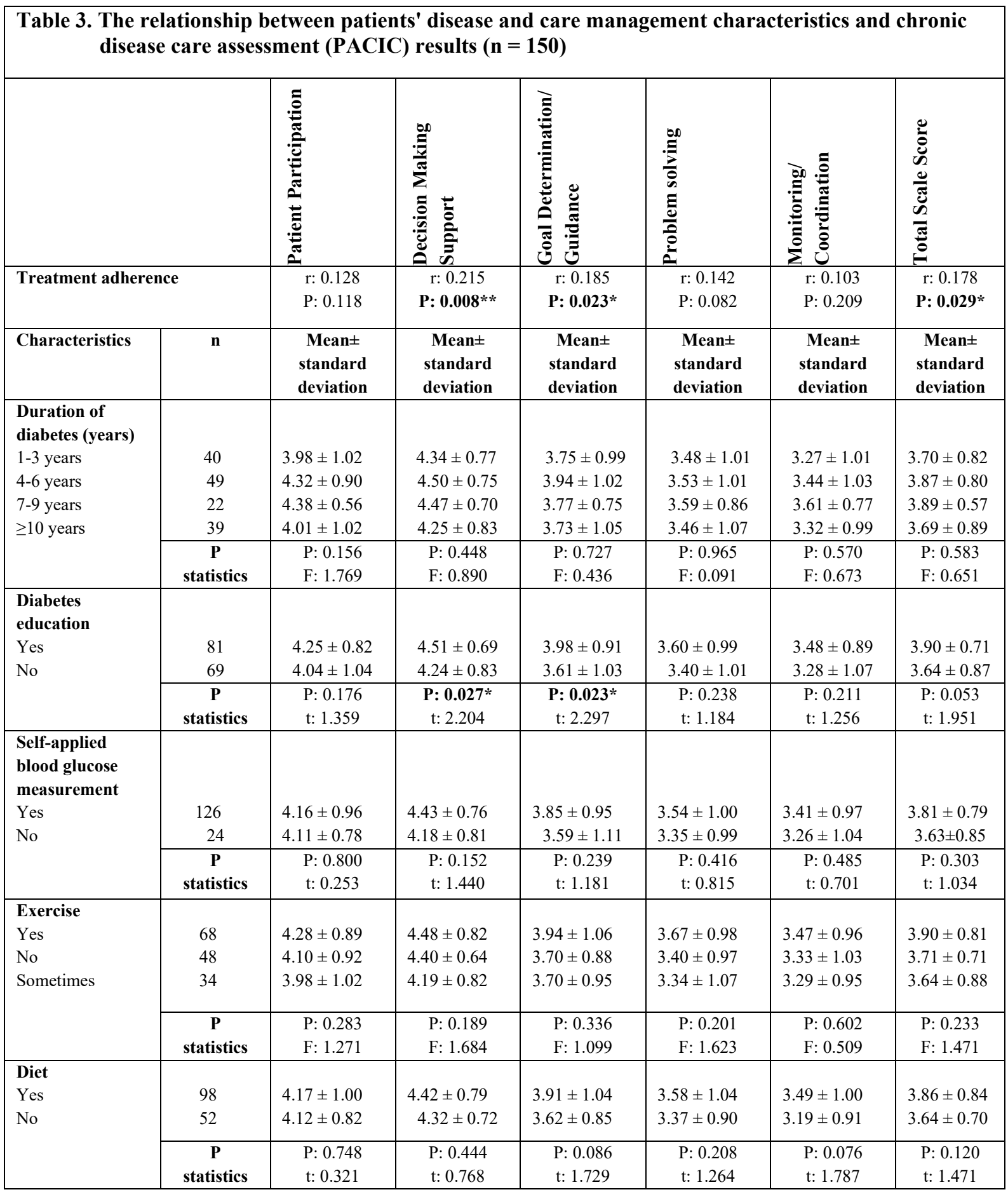

r: Pearson correlation coefficient, $\mathrm{t}$ : Independent groups $\mathrm{t}$ test, $\mathrm{F}$ : One-way analysis of variance, ${ }^{*} \mathrm{P}<0.05,{ }^{* *} \mathrm{P}<0.01$

There were a statistically significant correlation between EQ-5D-5L overall health score index value and PACIC decision-making support subscale scores ( $\mathrm{r}: 0.195, \mathrm{P}<0.05)$. There was a statistically significant correlation between EQ-5D$5 \mathrm{~L}$ overall health score index value and PACIC goal determination/guidance subscale scores (r: 0.165, P < 0.05) (Table 4). 


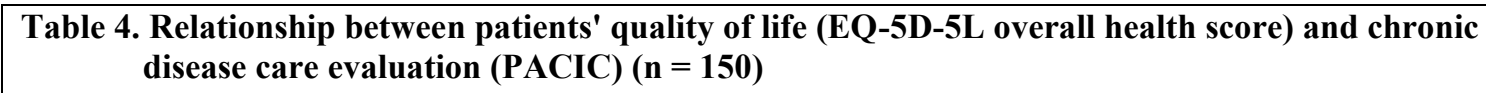

\begin{tabular}{lllll} 
& \multicolumn{2}{c}{ Overall Health Score } & (EQ-5D-5L) \\
\cline { 2 - 5 } & Index value & \multicolumn{2}{c}{ Visual Analog Scale } \\
& $\mathbf{( 0 - 1 )}$ & $\mathbf{( 0 - 1 0 0 )}$ \\
\cline { 2 - 5 } & $\mathbf{r}$ & $\mathbf{P}$ & $\mathbf{P}$ \\
\hline Patient ParticiPation & 0.154 & 0.061 & 0.060 & 0.462 \\
Decision making suPPort & 0.195 & $\mathbf{0 . 0 1 7 ^ { * }}$ & 0.096 & 0.242 \\
Goal determination/Guidance & 0.165 & $\mathbf{0 . 0 4 3}$ & 0.050 & 0.541 \\
Problem solving & 0.051 & 0.535 & -0.049 & 0.554 \\
Monitoring/Coordination & 0.043 & 0.599 & 0.004 & 0.962 \\
Chronic Disease Care & 0.132 & 0.108 & 0.029 & 0.725 \\
Evaluation (PACIC) Total Scale Score & & & & \\
\hline
\end{tabular}

r: Pearson correlation coefficient, $* \mathrm{P}<0.05$

\section{DISCUSSION}

Quality of life is an important component of Type 2 diabetes care management. Low quality of life in individuals with Type 2 diabetes may lead to lack of motivation, socio-economic and cultural problems, and disruption of health promotion activities. Therefore, improving quality of life is the basis of health promotion programs for the improvement and maintenance of health. ${ }^{10}$ The chronic disease care model is a model that supports the protective and holistic care of individuals with Type 2 diabetes. This model can benefit individuals' active participation in their care and treatment, comprehensive information, and strengthening self-management support. ${ }^{11}$

In our study, there was a negative correlation between BMI and quality of life EQ$5 \mathrm{D}-5 \mathrm{~L}$ overall health score index $(\mathrm{r}:-0.224 ; \mathrm{P}<$ $0.01)$ and VAS score (r: -0.186; $\mathrm{P}<0.05)$. In parallel to our study results, Zyoud et al. ${ }^{12}$ conducted a study of 408 Type 2 diabetics and showed a significant relationship between BMI and quality of life. Rwegerera et al. ${ }^{13}$ found higher BMI is associated with a greater number of chronic and somatic diseases, and therefore may affect the quality of life. Saleh et al. ${ }^{14}$ stated that high BMI could lead to impaired quality of life by increasing the risk of developing complications related to Type 2 diabetes. Obesity, one of the most important health problems of our time, is a chronic disease that can cause psychological, social and medical problems that may adversely affect the quality of life. It was observed that quality of life decreases with the increase in obesity of individuals. ${ }^{15}$ In parallel with the literature, in our study quality of life decreased with obesity in people with Type 2 diabetes. Supporting medical nutrition therapy and creating exercise plans, providing psychological support, reducing body image anxiety and developing training programs should be targeted in the management of patients with Type 2 diabetes and weight problems.

The HbAlc value is an indicator of the risk of complications during follow-up of metabolic control in Type 2 diabetes. Patients with poor metabolic control have a poor quality of life. ${ }^{16} \mathrm{In}$ this study, HbAlc values of the patients were found to be $7.42 \pm 1.28$. A significant negative correlation was found between $\mathrm{HbAlc}$ and EQ-5D-5L overall health score index (r: $-0.188 ; \mathrm{P}<0.05)$ and VAS score (r: $-0.225 ; \mathrm{P}<0.01)$. Sundaram et al. ${ }^{17}$ reported that if the $\mathrm{HbA} 1 \mathrm{c}$ level was below $7.0 \%$, the quality of life was better.

In this study, it was found that $32.7 \%$ of patients had a diagnosis of Type 2 diabetes for 4 to 6 years, $41.3 \%$ had oral antidiabetic drug (OAD) therapy with insulin therapy, and $43.8 \%$ had been using insulin for 1-3 years. Bourdel-Marchasson et al. ${ }^{18}$ in a study conducted with 2,832 Type 2 diabetics found $24.1 \%$ of the patients were diagnosed with Type 2 diabetes for 5-9 years and $10.7 \%$ of them received insulin + OAD treatment. In the study conducted by Yanık and Erol $^{19}$ with 230 Type 2 diabetic patients, the mean duration of diagnosis was $9.5 \pm 6.9$ years, and $23 \%$ of them received insulin + OAD treatment. D'Souza et al. ${ }^{20}$ in a study conducted with 140 Type 2 diabetics identified that $44.3 \%$ of the patients were diagnosed for 5-10 years, and $27.1 \%$ were treated with insulin + OAD. Zyoud et al. ${ }^{21}$ study conducted with 408 patients with Type 2 diabetes had an average of $12 \pm 8.8$ years diagnosis and $60 \%$ of 
patients received insulin $+\mathrm{OAD}$ treatment. It was observed that the rates of diagnosis and treatment regimen varied in our study. It was reported that the duration of Type 2 diabetes may adversely affect metabolic control and treatment compliance. ${ }^{22}$ Arslan found that $46.6 \%$ of patients with Type 2 diabetes who had less than 5 years of diagnosis were compliant with treatment. ${ }^{23}$ In our study in contrast to the literature findings, the majority $(40.7 \%)$ of the patients stated that although the duration of the disease was 7 years and over, the majority $(70.7 \%)$ had good compliance with the treatment.

In our study, it was determined that $46 \%$ of the patients had not received Type 2 diabetes education from their health professionals. There was also a significant difference between the patients receiving Type 2 diabetes education and PACIC decision-making support $(\mathrm{P}<0.05)$ and goal identification/guidance $(\mathrm{P}<0.05)$ subdimension scores. The rate of receiving education in the studies was $42.1 \%$ in the study by D'Souza et al. $^{20}, 60 \%$ in the study by Ustaalioglu ${ }^{24}$ and $29.3 \%$ in the study by Yildırım. ${ }^{25}$ Szecsenyi et al. ${ }^{26}$ in their research on Type 2 diabetes $(n=1399)$ found $61.7 \%$ of the patients were registered in the disease management program and PACIC $=$ subscale scores were highest for the decision-making support score. In most of the literature, the rate of participation in education was insufficient, as in our study. Among the possible causes of the inadequacy of participation in the education programs for Type 2 diabetics are reluctance, lack of awareness, and insufficient social support. The study by Arslan $(n=400)$ observed that patients attending the training program had higher compliance with treatment. ${ }^{23}$

Compliance with treatment in diabetes is the main determinant of treatment success. Lack of adaptation to treatment constitutes an obstacle to improving the quality of life. In patients with Type 2 diabetes, incompatibility leads to insufficient glycaemic control and long-term complications. ${ }^{27}$ In our study, it was concluded that $45.3 \%$ of the patients had regular exercise and $65.3 \%$ of them followed their diet. When asked about the patient's compliance with the treatment, $45.3 \%$ considered their compliance as good. In the study by Akgüç ${ }^{28}$ $(\mathrm{n}=100), 25 \%$ of the patients regularly followed their diet and $41 \%$ had regular exercise. Arslan and et al. ${ }^{23}$ reported that $(n=400), 57.3 \%$ of the patients had good adherence to treatment and $41.7 \%$ of them followed their diet. In the study by Baykal and Kapucu $(\mathrm{n}=157)$, it was observed that $56.8 \%$ of the patients exercised and $78.3 \%$ of the patients were dieting. ${ }^{29}$ In our study, there was a significant relationship between the compliance level with treatment and the total PACIC score, decision support and goal-setting/guidance subdimension scores. When we examine the literature, it was seen that the glycaemic values of patients with high compliance to treatment were more normal. ${ }^{22}$ Our results are similar to the literature. Diet and exercise compliance in patients with Type 2 diabetes improves the quality of life by reducing the risk of complications. ${ }^{16}$

In our study, there was a significant difference between the quality of life of the patients based on their treatment compliance and diet. Zyoud et al. reported a correlation between treatment compliance and quality of life. ${ }^{12}$ The study of Bradley et al. also stated that possible health problems related to treatment regimen could adversely affect treatment compliance and quality of life. ${ }^{30}$

In this study, there was a statistically significant relationship between the quality of life EQ-5D-5L general health score index and PACIC decision support and goal identification/guidance sub-dimension scores. This result can be interpreted as related to the decreased risk of disease-related complications in patients with chronic disease care management and the improved quality of life.

For support of Type 2 diabetes selfmanagement, it is foreseeable that guiding the goalsetting process of individuals leads to a higher quality of life by increasing the decision-making power of Type 2 diabetes patients in chronic disease management. In the process of chronic disease management, the aim should be to establish a special care program for Type 2 diabetes, to establish a follow-up/coordination system and to evaluate the results, and to raise awareness of diabetes with education and support of Type 2 diabetes self-management among Type 2 diabetes patients. Thus, the quality of life and satisfaction can be increased by meeting the care needs of individuals with Type 2 diabetes.

\section{Limitation of the study}

Since the study was conducted only in a university hospital, the results cannot be generalized to all Type 2 diabetes patients

\section{Acknowledgement}

The authors are grateful to Type 2 diabetes patients who participated in the study. 


\section{Conflict of interest}

The authors declared no potential conflicts of interest about the research, authorship, and/or publication of this article.

\section{REFERENCES}

1. Beaglehole R, Epping-Jordan J, Patel V, et al. Improving the prevention and management of chronic disease in low-income and middle-income countries: a priority for primary health care Lancet. 2008;372(9642):940-9. PMID: 18790317; doi: 10.1016/S0140-6736(08)61404-X.

2. International Diabetes Federation (IDF). Diabetes Atlas- $8^{\text {th }}$ ed. IDF; 2017. ISBN: 978-2930229-87-4. Available from: http://diabetesatlas.org/IDF_Diabetes_Atlas_8e_int eractive_EN/.

Accessed in 2019 (Apr 17).

3. Satman I, Omer B, Tutuncu Y, el al. Twelveyear trends in the prevalence and risk factors of diabetes and prediabetes in Turkish adults. Eur $\mathrm{J}$ Epidemiol. 2013;28(2):169-80. PMID: 23407904; doi: 10.1007/s10654-013-9771-5.

4. International Diabetes Federation (IDF). Diabetes Atlas-7 th $^{\text {th }}$ ed. IDF; 2015. ISBN: 978-2930229-81- $2 . \quad$ Available from: https://www.idf.org/e-library/epidemiologyresearch/diabetes-atlas/13-diabetes- atlas-seventhedition.html). Accessed in 2019 (Apr 17).

5. Kahn CR, Weir GC, King GL, et al. Diabetes: Definition, genetics and pathogenesis. Joslin's

Diabetes Mellitus. 2008; İstanbul Tıp Kitabevi. İstanbul pp.331-41.

6. Nutting PA, Dickinson WP, Dickinson LM, et al. Use of chronic care model elements is associated with higer-quality care for diabetes. Ann Fam Med. 2007;5(1):14-20. PMID: 17261860; doi: 10.1370/afm.610

7. EQ-5D-5L User Guide, EuroQol Group, Basic Information on how to use the EQ-5D-5L

Instrument, Version 2.1, 2015. Date of access: 16.05.2017. Available from:

https://euroqol.org/wp-

content/uploads/2016/09/EQ-5D

5L_UserGuide_2015.pdf. Accessed in 2019 (Apr 17).

8. Glasgow RE, Wagner EH, Schaefer J, et al. Development and validation of the patient assessment of chronic illness care (PACIC). Medical Care. 2005;43(5):436-44. PMID: 15838407.

9. İncirkuş K, Nahcivan NÖ. Kronik hastalık bakımını değerlendirme ölçeği-hasta formu'nun Türkçe versiyonunun geçerlik ve güvenirliği. DEUHYO ED. 2011;4(1):102-9. Available from: https://toad.halileksi.net/sites/default/files/pdf/kroni k-hastalik-bakimini-degerlendirme-olcegitoad.pdf. Accessed in 2019 (Apr 17).

10. Fransen MP, Beune EJ, Baim-Lance AM, Bruessing RC, Essink-Bot ML. Diabetes selfmanagement support for patients with low health literacy: perceptions of patients and providers. J Diabetes. 2015;7(3):418-25. PMID: 25042519; doi: 10.1111/1753-0407.12191.

11. Wagner EH, Austin BT, Davis C, et al. Improving chronic illness care: Translating evidence into action interventions that encourage people to acquire self-management skills are essential in chronic illness care. Health Affairs. 2001;20(6):64-78. PMID: 11816692; doi: $10.1377 /$ hlthaff.20.6.64.

12. Zyoud SH, Al-Jabi SW, Sweileh WM, et al. Relationship of treatment satisfaction to healthrelated quality of life among Palestinian patients with type 2 diabetes mellitus: Findings from a cross- sectional study. J Clin Transl Endocrinol. 2015;2(2):66-71. PMID: 29159112; doi: 10.1016/j.jcte.2015.03.002.

13. Rwegerera GM, Moshomo T, Gaenamong M, et al. Health-related quality of life and associated factors among patients with diabetes mellitus in Botswana. Alex J Med. 2018;54(2):111-8. doi: 10.1016/j.ajme.2017.05.010.

14. Saleh F, Ara F, Mumu SJ, Abdul Hafez A. Assessment of health-related quality of life of Bangladeshi patients with type 2 diabetes using the EQ-5D: a cross-sectional study. BMC Res Notes. 2015;8(497):1-8. PMID: 26420245; doi: 10.1186/s13104-015-1453-9.

15. Son N. Assessment of body perception, psychological distress, and subjective quality of life among obese and nonobese subjects in Turkey. Nigerian Journal of Clinical Practice. 2017;20(10):1302-8. doi: 10.4103/11193077.219509 .

16. Kara K, Çinar S. The relation between diabetes care profile and metabolic control variables. Kafkas J Med Sci. 2011;1(2):57-63.

doi: $10.5505 / \mathrm{kjms} .2011 .41736$. 
17. Sundaram M, Kavookjian J, Patrick JH. Healthrelated quality of life and quality of life in type 2 diabetes: relationships in a cross-sectional study. Patient. 2009;2(2):121-33. PMID: 22273088 doi: 10.2165/01312067-200902020-00008.

18. Bourdel-Marchasson I, Druet C, Helmer C, et al. Correlates of health-related quality of life in French people with type 2 diabetes. Diabetes Research and Clinical Practie. 2013;101(2):226-35. PMID: 23831112;

doi: 10.1016/j.diabres.2013.05.011.

19. Yanık YT, Erol Ö. Evaluation of self-efficacy levels of individuals with type 2 diabetes. Journal of Anatolia Nursing and Health Sciences. 2016;19(3):166-74. doi: 10.17049/ahsbd.22818.

20. D'souza MS, Karkada SN, Parahoo $\mathrm{K}$, et al. Self-efficacy and self-care behaviours among adults with type 2 diabetes. Appl Nurs Res. 2017;36:25-32. PMID: 28720235;

doi: 10.1016/j.apnr.2017.05.004.

21. Zyoud SH, Al-Jabi SW, Sweileh WM, et al. Relationship of treatment satisfaction to healthrelated quality of life among Palestinian patients with type 2 diabetes mellitus: Findings from a cross-sectional study. J Clin Transl Endocrinol. 2015;2(2):66-71.

PMID: 29159112; doi: 10.1016/j.jcte.2015.03.002.

22. Kitzler TM, Bachar M, Skrabal F, Kotonko P. Evaluation of treatment adherence in type 1 diabetes: a novel approach. Eur J Clin Invest. 2007;37(3):207-13. PMID:17359488; doi: $10.1111 / \mathrm{j} .1365-2362.2007 .01771 . x$.

23. Arslan E. Factors affecting compliance of patients with type 2 diabetes mellitus [thesis].

Diyarbakır,Turkey: Dicle University, Faculty of Medicine; 2011;31-42.

24. Ustaalioğlu S, Tan M. Examination of type 2 diabetics attitudes and behaviours against care and treatment. GUSBD. 2017;6(4):12-20. Available from: http://dergipark.gov.tr/download/articlefile/370763. Accessed in 2019 (Apr 17).

25. Yildirım D. Evaluation of the care needs of adults with type 1 diabetes; preliminary study to develop a maintenance model [thesis]. İstanbul, Turkey: İstanbul University, Health Sciences Institute; 2013;37-47.

26. Szecseny1 J, Rosemann $T$, Joos S, PetersKlımm F, Mıksch A. German diabetes disease management programs are appropriate for restructuring care according to the chronic care model. Diabetes Care. 2008;31(6):1150-4. PMID: 18299443; doi: 10.2337/dc07-2104.

27. Miller AT, Dimatteo MR. Importance of family/social support and impact on adherence to diabetic therapy. Diabetes Metab Syndr Obes. 2013;6:421-6. PMID: 24232691; doi: $10.2147 /$ DMSO.S36368.

28. Akgüç N. Evaluation of disease perception and treatment compliance in patients with type 2 diabetes [thesis]. İstanbul, Turkey: Haliç University, Health Sciences Institute; 2013;55-109.

29. Baykal A, Kapucu S. Type II diabetes mellitus patients' adherence to treatment. Journal of Hacettepe University Faculty of Nursing. 2015;2(2):44-58. Available from: http://dergipark.gov.tr/download/article-file/88663. Accessed in 2019 (Apr 17).

30. Bradley C, de Pablos-Velasco P, Parhofer KG, et al. Panorama: A European study to evaluate quality of life and treatment satisfaction in patients with type-2 diabetes mellitus-study design. Primary Care Diabetes. 2011;5(4):231-9. PMID: 21752743; doi: 10.1016/j.pcd.2011.04.004. 